DOI https://doi.org/10.30525/978-9934-588-47-1.16

\title{
ВПЛИВ РІЗНИХ МЕТОДІВ ТЕРМІЧНОЇ ОБРОБКИ НА ТЕХНОЛОГІЮ М'ЯСНИХ ДЕЛІКАТЕСІВ СПЕЦІАЛЬНОГО ПРИЗНАЧЕННЯ
}

\author{
Пешук Л. В., Сімонова I. I.
}

\section{ВСТУП}

Харчування $є$ одним із найважливіших чинників, що визначають стан здоров'я населення. Раціональне харчування необхідне для підтримання нормального функціонування здорового організму. М'ясо і продукти 3 нього є одними 3 найцінніших в харчуванні людини. Тому вдосконалення асортименту м'ясних продуктів повинні грунтуватися на концепції збалансованого харчування i враховувати енергетичну, біологічну та харчову цінність кожного продукту ${ }^{1,2,3}$. Особливе місце займають продукти спеціального призначення 3 підвищеною біологічною цінністю ${ }^{4}$. Значним попитом користуються в Україні м'ясо птиці та кроля. Ураховуючи високу біологічну цінність, м'ясо індиків та кролів рекомендують включати в меню людям усіх вікових груп, а також широко використовувати в лікувальному харчуванні ${ }^{5,6}$.

${ }^{1}$ Peshuk L.V., Galenko O.O., Budnik N.V. Use of collagenase in technology gerodietetic products. Journal of food and packing science, technique and technologies. 2014. 2(3). P. 8-11.

2 Пешук Л.В., Гащук О.I, Москалюк О.Є. Інноваційні м'ясні продукти. Харчова промисловість. 2015. 17. С. 64-67.

${ }^{3}$ Simonova I., Peshuk L. Galenko J. Microscopic examinayion of chops with content of lentil flour. Ukranian Journal of Food Science. 2019. Volume 7. Issue 1. P.16-26. DOI: 10.24263/2310-1008-2019-7-1-4.

${ }^{4}$ Brenes A., Viveros A., Chamorro S., Arija I. Use of polyphenol-rich grape byproducts in monogastric nutrition. A review. Animal Feed Science and Technology. 2016. Volume 211. P. 1-17. DOI.org/10.1016/j.anifeedsci.2015.09.016.

5 Dal A., Simona B., Marco C. M., Szendrő Z., Gerencsér Z., Matics Z., Castellini C., Szin M., Zotte A. Effect of diet and packaging system on the oxidative status and polyunsaturated fatty acid content of rabbit meat during retail display. Meat Science. 2018. Volume 143. P. 46-51. DOI.org/10.1016/j.meatsci.2018.04.004.

6 Спосіб виробництва сиров'ялених продуктів із м'яса індиків і кролів «Торіно»: пат. на винахід 104679 Україна: МПК 51 А 23 С 11 /00 Пешук Л.В., Дидюк О.Ю., Дубяга О.М; власник НУХТ. № а201214239; заявл. 13.12.2012; опубл. 25.02.2014, Бюл. № 10. 
Особливо корисно м'ясо індиків та кролів для дітей, людей похилого віку й осіб 7 , що страждають на зайву вагу, оскільки має невисоку калорійність (736,38 та 765,67 кДж). Науковці працюють над можливістю використання індиків та кролів у технологіях ковбас, копченостей, посічених напівфабрикатів, м'ясних консервах ${ }^{8}$. Вивчено хімічний склад фрикадельок, гамбургерів, сосисок, шинок та рулетів ${ }^{9}$. Готові вироби характеризуються збалансованим амінокислотним та жирно-кислотним складом, багаті на мінеральні речовини такі як кальцій, залізо, фосфор, магній, калій, натрій, цинк ${ }^{10}$.

Із метою подовження терміну зберігання готових виробів в рецептуру вводять природні антиоксиданти ${ }^{11}$. Розмарин, шавлія, червоний та чорний перець, майоран, екстракт виноградних кісточок пригнічують окиснення ліпідів та подовжують терміни зберігання виробів ${ }^{12}$. В останні роки актуальним в технологіях м'ясних виробів $\epsilon$ використання олеорезинів.

Вони є складною багатокомпонентною сумішшю натуральних органічних речовин, які в порівнянні із прянощами містять у 10 разів більше ефірних олій, окрім антиоксидантних властивостей, покращують органолептичні показники готових виробів. Оскільки

${ }^{7}$ José Manuel. Identification and quantification of turkey meat adulteration in fresh, frozen-thawed and cooked minced beef by FT-NIR spectroscopy and chemometrics. Meat Science. 2016. Volume 121. P. 175-181. DOI.org/10.1016/j.meatsci.2016.06.018.

${ }^{8}$ Cullere M., Dalle A., Zotte, Tasoniero G., Giaccone V., Szendrő Z., Szín M., Odermatt M., Gerencsér Z., Dal Bosco A., Matics Z. Effect of diet and packaging system on the microbial status, $\mathrm{pH}$, color and sensory traits of rabbit meat evaluated during chilled storage. Meat Science. 2018. Volume 141. P. 36-43. DOI.org/10.1016/j.meatsci.2018.03.014.

${ }^{9}$ Mancini S., Nuvoloni R., Pedonese F., Paci G. Effects of garlic powder and salt additions in rabbit meat burgers: Preliminary evaluation. Food processing and precervation. 2019. Volume 133,3. P. 1-10. DOI.org/10.1111/jfpp.13894.

${ }^{10}$ Ding Y., Lin H.-W., Lin Y.i-L., Yang D.-J., Yu Y.-S., Chen Jr.-W., Wang S.Y., Chen Y.-C. Nutritional composition in the chia seed and its processing properties on restructured ham-like products. Journal of Food and Drug Analysis. 2018. Volume 26(1). P. 124-134. DOI.org/10.1016/j.jfda.2016.12.012.

${ }_{11}$ Youling J. J., Xiong L. Natural antioxidants as food and feed additives to promote health benefits and quality of meat products: A review. Meat Science. 2016. Volume 120. P. 107-117. DOI.org/10.1016/j.meatsci.2016.04.005.

${ }^{12}$ Mattioli S., Dal Bosco A., Szendrő Zs., Cullere M., Gerencsér Zs., Matics Zs., Castellini C., Dalle Zotte A. The effect of dietary Digestarom herbal supplementation on rabbit meat fatty acid profile, lipid oxidation and antioxidant content. Meat Science. 2016. Volume 121. P. 238-242. DOI.org/10.1016/j.meatsci.2016.06.024. 
частка м'ясних продуктів спеціального харчування із м'яса індиків і кролів на ринку України незначна, актуальним є вирішення завдань щодо розроблення технології м'ясних делікатесних шинок із даної сировини ${ }^{13}$.

\section{1. Технологічний процес виготовлення делікатесного продукту - шинок із м'яса індиків та кролів}

Мета роботи - розроблення технології делікатесних продуктів із м'яса індиків та кролів, дослідження різного впливу термічної обробки (варіння, коптіння та запікання) на фізико-хімічні, функціонально-технологічні, мікробіологічні характеристики готового продукту під час зберігання. Об'єкт досліджень технології шинок з м'яса індиків та кролів.

Для виробництва шинок методом математичного моделювання щодо оптимального вмісту білка в рецептурі готового продукту за незамінними амінокислотами встановлено співвідношеннях м'ясо індика і кроля 65 до 35 кг (таблиця 1). За контроль взято рулет «Курячий» ТУ У 15.1-30978685-006-2001.

Таблиця 1

Рецептура шинки вз м'яса індика і кроля

\begin{tabular}{|c|c|}
\hline \multicolumn{2}{|c|}{ Основна сировина, кг } \\
\hline Індика & 65 \\
\hline Кроля & 35 \\
\hline Прянощі та допоміжні матеріали, г на 100 кг несоленої сировини \\
\hline Сіль харчова & 2200 \\
\hline Нітрит натрію & 0,005 \\
\hline $\begin{array}{c}\text { Олеорезин римського } \\
\text { кмину }\end{array}$ & 0,8 \\
\hline Олеорезин перцю білого & 1 \\
\hline Вода & 30 л \\
\hline
\end{tabular}

Технологічний процес виробництва шинки проводився відповідно до технологічної інструкції і складався з таких етапів:

- вхідне контролювання і приймання сировини та матеріалів;

- підготовка сировини та матеріалів;

- приготування фаршу;

${ }^{13}$ Dalle A., Zotte C., Celia Zs., Szendrő. Herbs and spices inclusion as feedstuff or additive in growing rabbit diets and as additive in rabbit meat: A review. Livestock Science. 2016. Volume 189. P. 82-90. DOI.org/10.1016/j.livsci.2016.04.024. 
- визрівання фаршу;

- наповнення оболонок фаршем;

- термічна обробка;

- контролювання якості готової продукції;

- маркування, пакування, зберігання.

Термічну обробку дослідних зразків шинок проводили трьома способами: виготовлення шинки вареної проводили в термокамері «Novotherm» за такими етапами термообробки: підсушування за температури $45-50^{\circ} \mathrm{C}$ до появи рожевого кольору фаршу i підсихання поверхні оболонки, обжарювання димом за температури $85-90^{\circ} \mathrm{C}$, варіння у штучних білкових оболонках «Білкозин» (температура $75 \pm 2^{\circ} \mathrm{C}$ (40-80 хвилин)); охолодження 2-3 години холодним повітрям до температури $8^{\circ} \mathrm{C}$ в товщі батону.

Термічну обробку шинки копчено-вареної проводили в термокамері «Autotherm» таким чином: підсушували і обжарювали батони 15-30 хв. за температури $60 \pm 5{ }^{\circ} \mathrm{C}$, відносної вологості повітря 10-20\% і швидкості руху повітря $2 \mathrm{~m} / \mathrm{c}$; коптіння проводили відразу після обжарювання від 10 до 25 хв. за температури $75 \pm 5^{\circ} \mathrm{C}$ до досягнення в центрі батону температури $71 \pm 1^{\circ} \mathrm{C}$; варіння у штучних білкових оболонках проводили за температури $75 \pm 2^{\circ} \mathrm{C}$. Тривалість варіння - 55-60 хв. на 1 кг маси продукту в залежності від діаметра батону 40-60 хв., охолодження проводили холодним повітрям до температури $8^{\circ} \mathrm{C}$ в товщі батону.

Виготовлення шинки запеченої проводили в жарочній шафі «Агро-терм»: підсушували за температури $55-65^{\circ} \mathrm{C}$, відносної вологості $30 \%$ протягом 25-30 хв.; запікання проводили за різних температурних режимів до досягнення температури в центрі батону $72 \pm 1^{\circ} \mathrm{C}$ : на першій стадії термообробки запікали за температури $120^{\circ} \mathrm{C}$ до досягнення температури в товщі батону $28^{\circ} \mathrm{C}$; на другій стадії запікали за температури $130{ }^{\circ} \mathrm{C}$ до температури в товщі батону $35^{\circ} \mathrm{C}$ i на третій - запікали за температури $140^{\circ} \mathrm{C}$ до температури в батоні $72^{\circ} \mathrm{C}$. Охолоджували холодним повітрям до температури $8^{\circ} \mathrm{C}$.

Під час виконання досліджень використовували такі методи: фізико-хімічні (масова частка вологи, білка, жиру, золи, амінокислотний склад); функціонально-технологічні (вологоутримуюча, вологозв'язуюча, жироутримуюча здатності, пластичність); мікробіологічні (загальна кількість мезофільних аеробних та факультативно анаеробних мікроорганізмів, бактерій 
групи кишкової палочки (коліформи), патогенних мікроорганізмів, в т. ч. сульфідредукувальних клостридій, бактерій роду Proteus, Salmonella, Staphylococcus aureus, L. monocytogenes) $)^{14}$. Відносну біологічну цінність продукту і безпечність визначено in vivo на тест-організмах Tetrahymena pyriformis ${ }^{15}$. Аналіз експериментальних даних проводили з використанням методів розрахунку статистичної достовірності результатів досліджень.

\section{2. Результати досліджень делікатесного продукту - шинок із м'яса індиків та кролів}

Використання в рецептурі м'яса індика і кроля призводить до покращення якісних показників готових виробів, зокрема біологічної цінності. За вмістом білка розроблені шинки переважають контроль на $41 \%$ (шинка варена), 42,1\% (шинка копчено-варена), 43,5\% (шинка запечена). За вмістом жиру - на $53,9 \%$ менше порівняно з контролем (табл. 2). Отже, розроблений продукт має дієтичні властивості.

Таблиця 2

Хімічний склад готових виробів

\begin{tabular}{|c|c|c|c|c|c|c|}
\hline $\begin{array}{c}\text { № } \\
\mathbf{n} / \\
\mathbf{I}\end{array}$ & $\begin{array}{c}\text { Найменува } \\
\text { ння виробу }\end{array}$ & $\begin{array}{c}\text { Вміст } \\
\text { вологи, } \\
\text { \% }\end{array}$ & Білок, \% & Жир, \% & Зола, \% & $\begin{array}{c}\text { Кало- } \\
\text { рійність } \\
\text { кДж }\end{array}$ \\
\hline 1 & Контроль & $65,41 \pm 1,0$ & $12,30 \pm 0,1$ & $17,42 \pm 0,07$ & $4,87 \pm 0,01$ & 862,39 \\
\hline 2 & $\begin{array}{c}\text { Шинка } \\
\text { варена }\end{array}$ & $67,28 \pm 1,1$ & $20,91 \pm 0,1$ & $9,30 \pm 0,04$ & $2,61 \pm 0,01$ & 717,19 \\
\hline 3 & $\begin{array}{c}\text { Шинка } \\
\text { копчено- } \\
\text { варена }\end{array}$ & $66,83 \pm 0,9$ & $21,25 \pm 0,4$ & $9,39 \pm 0,05$ & $2,51 \pm 0,02$ & 709,66 \\
\hline 4 & $\begin{array}{c}\text { Шинка } \\
\text { запечена }\end{array}$ & $65,94 \pm 1,0$ & $21,77 \pm 0,2$ & $9,59 \pm 0,05$ & $2,72 \pm 0,01$ & 725,94 \\
\hline
\end{tabular}

Оскільки фарш під час виготовлення шинок використовувався один, а термічна обробка - різна, нами проведено аналіз

${ }^{14}$ Маркович I.I. Зміни мікробіологічних показників напівкопчених ковбас у процесі зберігання. Наукові доповіді Національного університету біоресурсів $i$ природокористування України. 2015. № 3. Режим доступу: URL : http://nbuv.gov.ua/UJRN/Nd_2015_3_18.

${ }_{15}$ Drachuk U., Simonova I., Halukh B., Basarab I., Romashko I. The study of lentil flour as a raw material for production of semi-smoked sausages. Easterneuropean journal of enterprise technologies. 2018. № 6. 11 (96). P. 44-50. DOI:10.15587/1729-4061.2018.148319. 
амінокислотного складу шинок відповідно до температурних режимів. У фарші вміст незамінних амінокислот становив 5,03 мг на 100 мг продукту, у вареній шинці - 4,64, у запеченій $-4,98$, у копчено-вареній - 4,39. Для моніторингу впливу температурних режимів на якісний та кількісний склад білку проводили вивчення амінокислотного складу готових виробів (табл. 3).

Таблиця 3

Амінокислотний склад шинок

\begin{tabular}{|c|c|c|c|c|}
\hline \multirow[b]{2}{*}{ Амінокислота } & \multicolumn{4}{|c|}{ Кількість, мг амінокислоти/100 мг продукту } \\
\hline & Фарш & $\begin{array}{l}\text { Варена } \\
\text { шинка }\end{array}$ & $\begin{array}{c}\text { Запечена } \\
\text { шинка }\end{array}$ & $\begin{array}{c}\text { Копчено- } \\
\text { варена } \\
\text { шинка }\end{array}$ \\
\hline \multicolumn{5}{|c|}{ Незамінні амінокислоти } \\
\hline Валін & 0,617 & 0,445 & 0,612 & 0,537 \\
\hline Лейцин & 1,061 & 1,063 & 1,092 & 0,940 \\
\hline Ізолейцин & 0,562 & 0,415 & 0,546 & 0,477 \\
\hline Лізин & 1,192 & 1,156 & 1,224 & 1,062 \\
\hline Метіонін & 0,291 & 0,378 & 0,221 & 0,207 \\
\hline Фенілаланін & 0,572 & 0,532 & 0,574 & 0,507 \\
\hline Треонін & 0,734 & 0,650 & 0,715 & 0,658 \\
\hline Триптофан & \multicolumn{4}{|c|}{ Не досліджували } \\
\hline $\begin{array}{c}\text { Всього } \\
\text { незамінних } \\
\text { амінокислот }\end{array}$ & 5,029 & 4,639 & 4,984 & 4,388 \\
\hline \multicolumn{5}{|c|}{ Замінні амінокислоти } \\
\hline Гістидин & 0,430 & 0,487 & 0,451 & 0,397 \\
\hline Аргінін & 0,851 & 0,857 & 0,871 & 0,778 \\
\hline Аспараг. к-та & 1,343 & 1,315 & 1,255 & 1,133 \\
\hline Серин & 0,638 & 0,629 & 0,637 & 0,561 \\
\hline Глутамін. к-та & 2,772 & 2,670 & 2,761 & 2,458 \\
\hline Пролін & 0,613 & 0,546 & 0,550 & 0,541 \\
\hline Гліцин & 0,636 & 0,647 & 0,639 & 0,579 \\
\hline Аланін & 0,832 & 0,846 & 0,854 & 0,741 \\
\hline Цистин & 0,130 & 0,119 & 0,148 & 0,118 \\
\hline Тирозин & 0,506 & 0,416 & 0,492 & 0,425 \\
\hline $\begin{array}{l}\text { Всього замінних } \\
\text { амінокислот }\end{array}$ & 8,751 & 8,532 & 8,657 & 7,732 \\
\hline Сума: & 13,780 & 13,171 & 13,641 & 12,120 \\
\hline
\end{tabular}

У 100 мг продукту міститься певна кількість білка, а відповідно, й амінокислот. Але в процесі термічної обробки в різних продуктах по-різному виділилася волога. Наприклад, у запеченій шинці лише 
$65,94 \%$ вологи, в той час як у вареній iї - 67,25\%. Тому має місце аналіз як вмісту амінокислот в готових продуктах та фарші, так i вмісту амінокислот безпосередньо в білку з урахуванням різної кількості вологи в готових продуктах. Із таблиці 3 видно, що загальна сума амінокислот запеченої шинки становить 13,64 мг, що на 13,08 мг більше ніж, у копчено-вареній, на 11,56 мг - ніж у запеченій, на 0,47 мг - ніж у вареній.

Залежність між біологічною цінністю білків і їхнім амінокислотним складом може бути лише за умови достатньо високих швидкостей перетравлювання білків ферментами травного тракту. За амінокислотним складом і аналітичним розрахунком показників біологічної цінності можна отримати уявлення лише про потенційну цінність білкового компоненту продукту. Оскільки організм людини використовує не все, що надходить з їжею, а тільки те, що після перетравлювання у травному тракті всмоктується стінками кишечника у кров. Одним із основних показників, що визначає біологічну цінність харчових продуктів, $€$ ступінь перетравлення білків протеолітичними ферментами шлунково-кишкового тракту. Для дослідження цього нами проведено експеримент на культурах клітин інфузорії Tetrahymena pyriformis. Вони в морфологічному аспекті $\epsilon$ клітинами, а в фізіологічному - цілісним організмом. Тому перетравлення білків травними ферментами в умовах in vivo можна використовувати для прогнозування ступеня їх утилізації організмом. Iз метою визначення засвоюваності розроблених шинок в умовах $\mathrm{i}$ in vivo в порівнянні з контрольним зразком визначено відносну біологічну цінність.

Відносна біологічна цінність дослідних зразків із використанням даної сировини перевищує контроль у середньому на $28 \%$. Зокрема, в шинці вареній, копчено-вареній, запеченій цей показник становить, \%: 88,94; 89,34 та 96,68. Це пояснюється швидкістю розвитку клітин війчастих інфузорій Tetrahymena pyriformis кількість клітин, які виросли на поживному середовищі 3 використанням контрольного зразка, становить 288,34, а дослідних, кл/мм ${ }^{3}-421,18 ; 423,70$ та 456,51 відповідно (табл. 4).

Як видно 3 даних табл. 6, у зразку шинки запеченої відносна біологічна цінність має тенденцію до зростання і становить 96,68 \%. Такий результат пояснюється рецептурним складом. Коефіцієнт ефективності використання білка (КЕВБ) організмом у дослідних 
зразках шинок складає 0,19 - 0,22\% що на $35 \%$ більше порівняно 3 контролем. Ефективність біологічної дії під час засвоювання білка (ЕБД) щодо контрольного зразка значно вища у шинці запеченій $(93,34 \%)$ та копчено-вареній $(84,5)$. Стандартизована відносна білкова ефективність фаршів (СВБЕ) повніша порівняно 3 контролем у запеченій та копчено-вареній шинці. Цей показник становить 462,37\% та 418,5\%. Гіршим показником у порівнянні 3 контролем характеризуються шинка варена.

Таблиця 4

Порівняльна характеристика відносної біологічної цінності і відносної ефективності використання білка дослідних зразків

\begin{tabular}{|c|c|c|c|c|c|c|}
\hline 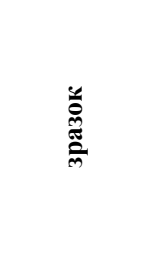 & 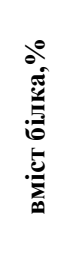 & 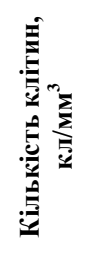 & 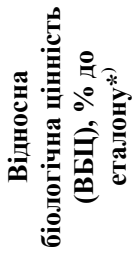 & 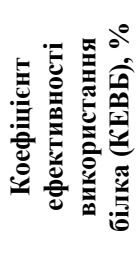 & 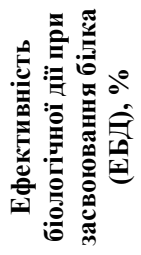 & 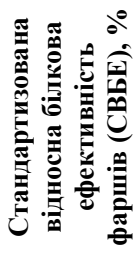 \\
\hline $\begin{array}{c}\text { Казеїн } \\
\text { молока }\end{array}$ & 100 & 473,25 & 100 & 0,04 & - & - \\
\hline $\begin{array}{c}\text { Контроль } \\
\text { рулет } \\
\text { «курячий» }\end{array}$ & 12,3 & 288,34 & 60,92 & 0,14 & - & 298,66 \\
\hline $\begin{array}{l}\text { Шинка } \\
\text { варена }\end{array}$ & $\begin{array}{c}20,9 \\
1\end{array}$ & 421,18 & 88,94 & 0,19 & 82,85 & 410,41 \\
\hline $\begin{array}{c}\text { Шинка } \\
\text { копчено- } \\
\text { варена }\end{array}$ & $\begin{array}{c}21,2 \\
5\end{array}$ & 423,70 & 89,34 & 0,19 & 84,5 & 418,50 \\
\hline $\begin{array}{c}\text { Шинка } \\
\text { запечена }\end{array}$ & $\begin{array}{c}21,7 \\
7\end{array}$ & 456,51 & 96,68 & 0,22 & 93,34 & 462,37 \\
\hline
\end{tabular}

Примітка: за еталон використовували поживне середовище з казеїном молока 

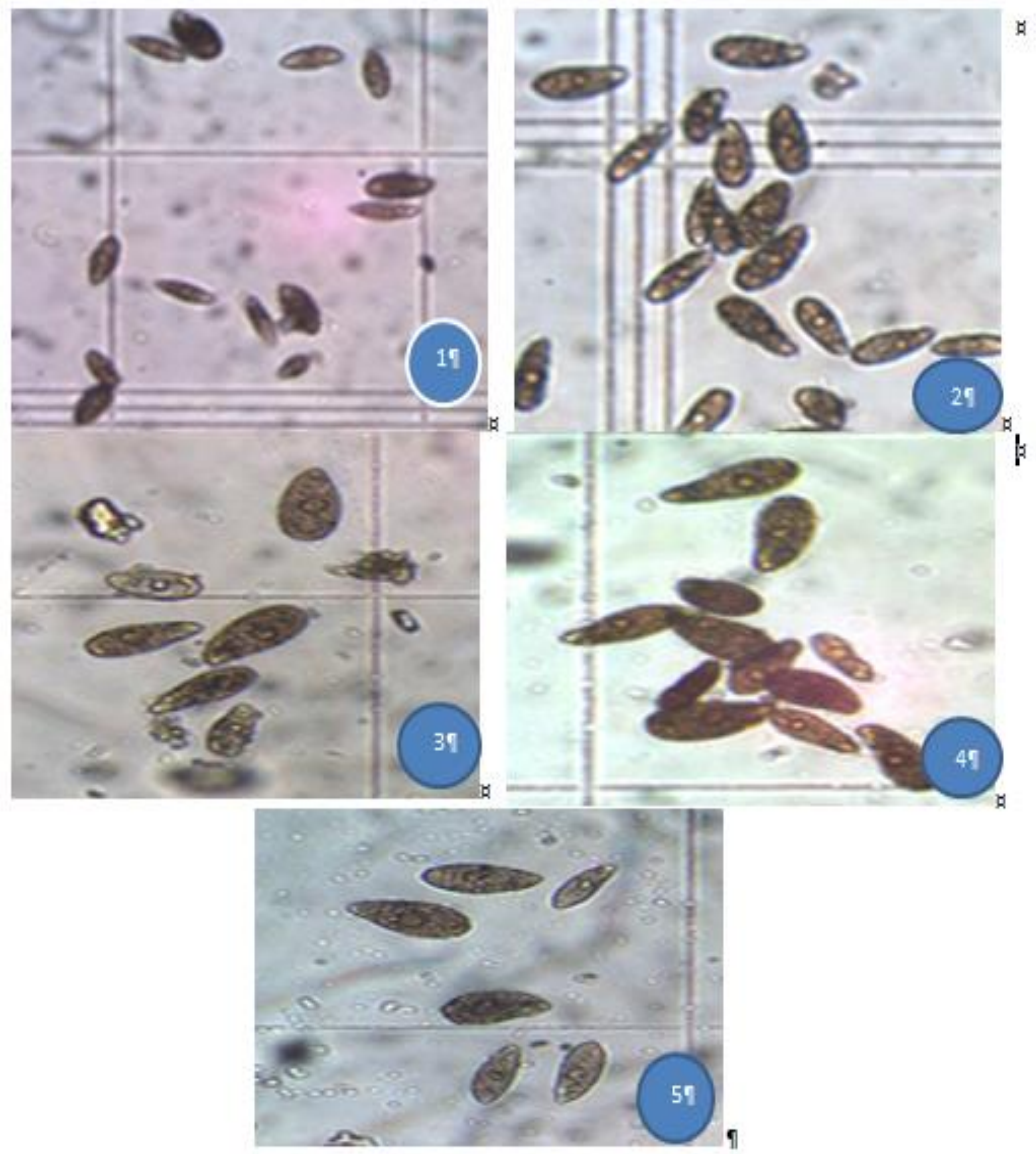

Рисунок 1. Морфологія клітин інфузорій Tetrahymena pyriformis за культивування в середовищах: 1 - казеїном молока;

2 - контролем; 3 - із шинкою вареною; 4 - із шинкою копчено-вареною; 5 - із шинкою запеченою

Слід зауважити, що під час проведення дослідження впливу допоміжної сировини на життедіяльність найпростіших організмів морфологічних змін клітин війчастих інфузорій Tetrahymena pyriformis не виявлено. Інфузорії, вирощені на середовищах із дослідними зразками, більш округлі, краще проглядаються, 
кількість клітин зростає порівняно з контролем. Отже, використана сировина не містить шкідливих та небезпечних сполук.

Визначення функціонально-технологічних властивостей (ФТВ) дає повну уяву про м'ясну систему, іiі структуру, здатність поглинати та утримувати вологу під час теплової обробки. Урахування функціонально-технологічних властивостей м'ясної сировини дозволяє раціонально використовувати іiі, прогнозувати та направлено регулювати якісні характеристики готових виробів. Результати досліджень функціонально-технологічних властивостей м'ясних фаршів наведено в таблиці 5.

Таблиця 5

Функціонально-технологічні властивості м'ясних фаршів

\begin{tabular}{|c|c|c|c|c|c|}
\hline 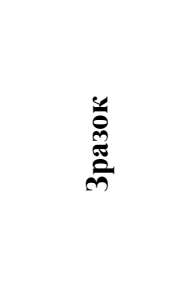 & 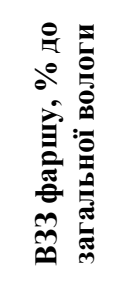 & $\begin{array}{l}0 \\
0 \\
\theta \\
\theta\end{array}$ & 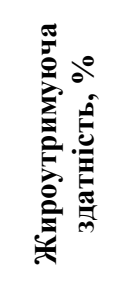 & 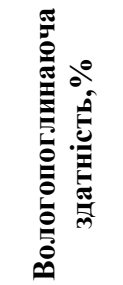 & 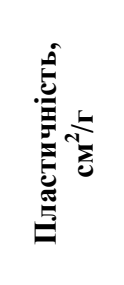 \\
\hline Контроль & $87,1 \pm 1,1$ & $90,5 \pm 0,7$ & $71,4 \pm 1,1$ & $83,3 \pm 1,1$ & $7,76 \pm 0,1$ \\
\hline $\begin{array}{c}\text { Фарш шинки } \\
\text { вареної, } \\
\text { копчено- } \\
\text { вареної, } \\
\text { запеченої }\end{array}$ & $89,3 \pm 0,9$ & $72,6 \pm 0,9$ & $73,8 \pm 1,0$ & $84,8 \pm 1,2$ & $8,53 \pm 0,1$ \\
\hline
\end{tabular}

Шинки варена, копчено-варена та запечена виготовлені з одного фаршу, тому для визначення стабільності фаршевої емульсії, волозв'язуючої (ВЗ3), жиро- (ЖУЗ) та вологопоглинаючої (ВУЗ) здатностей відбирали лише один зразок. Дослідні зразки шинок переважали контроль за ВВ3 фаршу до загальної вологи на 2,2\%, ЖУЗ - на 2,4\% та ВУЗ - що на 1,5\% краще, ніж у контрольному зразку відповідно. Пластичність шинок вареної, копчено-вареної, запеченої вища на $0,77 \%$ за контроль і становить $8,53 \%$.

Одним із важливих факторів, який необхідно враховувати під час виробництва шинкових виробів, є їхня здатність зберігати якісні характеристики протягом усього терміну придатності.

Для виробництва шинок вареної та варено-копченої використано штучні білкові оболонки «Білкозин». Їхніми перевагами $\epsilon$ 
еластичність, забезпечення стабільності діаметру, зберігання форми виробу під час охолодження та у процесі зберігання, висока паро- та газопроникність, отримання традиційного смаку та натурального вигляду продукту. Куряча шкурка була використана для запеченої шинки. Із метою захисту готових виробів від окислювального псування використовували олеорезини римського кмину та білого перцю. Їхня дія спрямована на блокування активних радикалів у ланцюгових реакціях окиснення. Окислення ліпідів починається в субклітинних мембранах у фракції високоненасичених фосфоліпідів. Здатність до окислення ненасичених жирних кислот, особливо із двома і більше подвійними зв'язками, під час зберігання призводить до прогіркання і погіршення кольору м'яса. Зміни якості шинок проходять за взаємопов'язаними напрямами - окисні, мікробіологічні й фізичні процеси. Виходячи із цього, ми дослідили зміни показників окиснення жиру та мікробіологічних показників шинок під час зберігання.

Гідролітичні та окиснювальні перетворення ліпідів, що відбуваються за тривалого зберігання, переважно не мікробного походження. Проте в ліполітичних бактеріях, плісені та інших мікроорганізмів містяться ферментні системи, що спричиняють гідролітичні та окиснювальні перетворення ліпідів. Ліпази цих мікроорганізмів активно каталізують гідроліз ліпідів. Найбільш чутливими до окиснювального перетворення є ненасичені жирні кислоти та насичені жирні кислоти 3 коротким ланцюгом. Високомолекулярні жирні кислоти стійкіші до таких перетворень.

Під час зберігання відбувається гідролітичний розпад, глибина якого визначається вмістом вільних жирних кислот i характеризується величиною кислотного числа. Гідролізований жир добре засвоюється організмом людини, однак при глибокому гідролізі жирні кислоти, що утворюються у великій кількості, сприяють розвитку окисних процесів. Під час дослідження вмісту летких жирних кислот вироби вважають свіжими, якщо вміст летких жирних кислот становить до 4,5 мгКОН/Г, сумнівної свіжості - 4,9 до 9 мгКОН/г, несвіжими - більше 9 мгКОН/г.

Під час зберігання шинок за температури $0 \ldots 6{ }^{\circ} \mathrm{C}$ накопичення летких жирних кислот активно спостерігалось на 10 добу, де вони мали сумнівну свіжість, а після 15 діб - зіпсувались. Накопичення

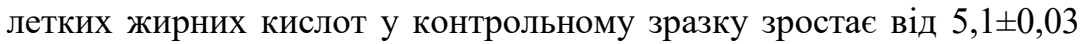
до $11 \pm 0,01$ мг КОН/г. 
Після 10 доби зберігання копчено-варена та варена шинки

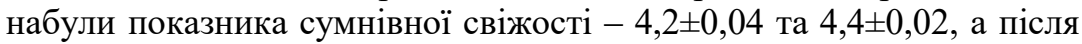

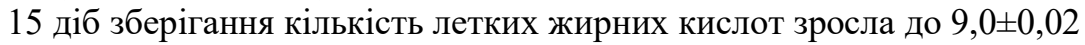
та 9,5 $\pm 0,02$, вироби були зіпсовані (рисунок 2).

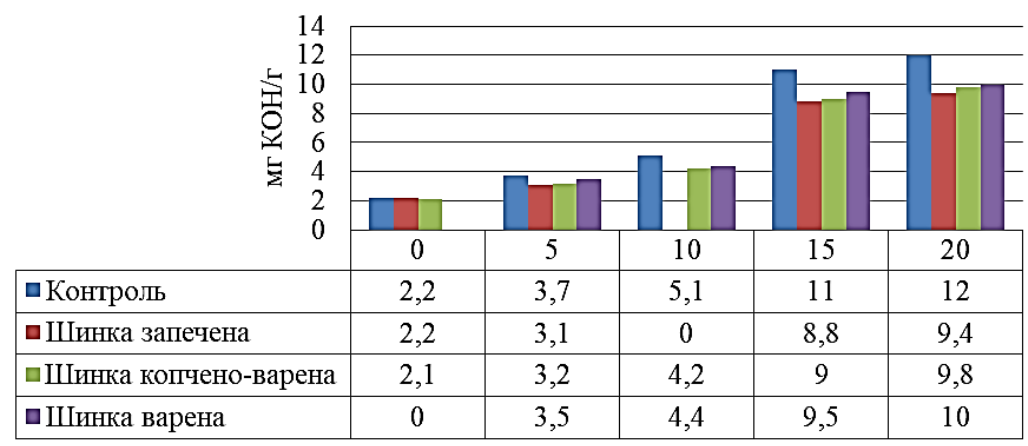

\section{Рисунок 2. Динаміка зміни летких жирних кислот ліпідів шинок під час зберігання, мгКОН /г}

Шинка, упакована під вакуумом цілими виробами, на початку експерименту була свіжою. Вміст летких жирних кислот у контролі становив 2,5 $\pm 0,01$ мгКОН /г у шинці запеченій і копчено-вареній -

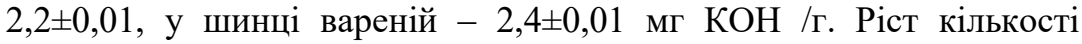
летких жирних кислот помітний на 10 та 15 день зберігання, що відповідає їх сумнівній свіжості, зокрема в контролі їх вміст

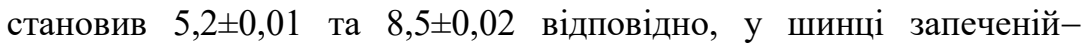
$4,6 \pm 0,02$ та 5,5 $\pm 0,02$, шинці копчено-вареній- $4,8 \pm 0,01$ та $6,2 \pm 0,01$,

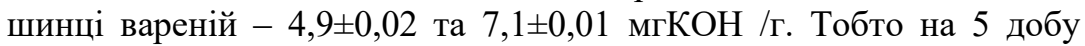
зберігання усі дослідні шинки були свіжими.

За результатами досліджень встановлено, що вироби були зіпсовані після 20 днів, окрім шинки запеченої, яка була сумнівної

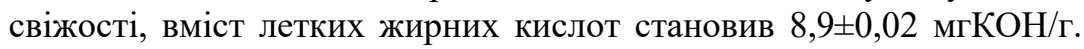
Накопичення летких жирних кислот контрольного зразка переважає їх вміст у шинці запеченій на 25\% та становить $12,2 \pm 0,01 \mathrm{мгКОН/г;}$ у шинках копчено-вареній та вареній цей показник становить $19,7 \pm 0,02$ та 10,9 $\pm 0,01$ мгКОН /г (рисунок 3$)$. 


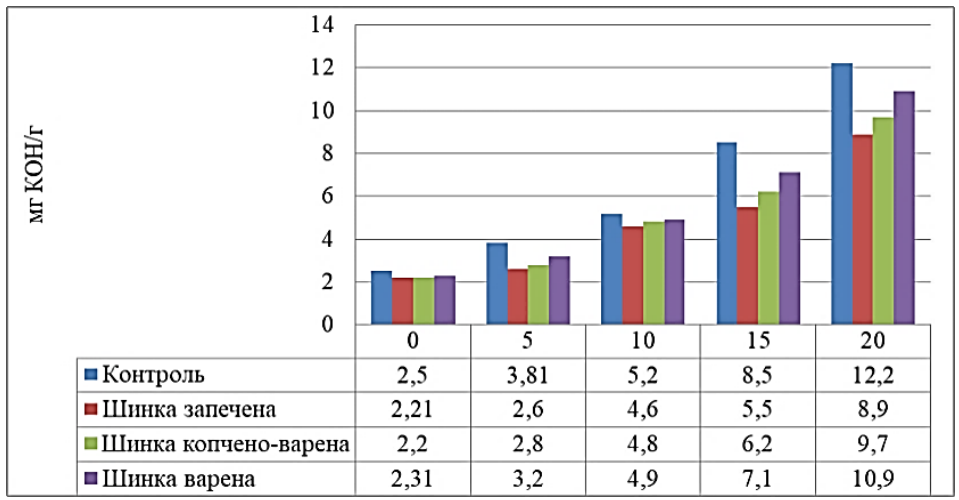

Рисунок 3. Динаміка зміни летких жирних кислот ліпідів шинок, упакованих під вакуумом, мгКОН /Г

Зміни кислотного числа шинок, що зберігались у холодильних умовах, можна прослідкувати після 10 доби зберігання. За зміною значення цього показника після 15 діб можна стверджувати про псування виробів.

У контрольному зразку кислотне число на 5 добу зберігання становить $3,6 \pm 0,01$, а на 15 добу $-6,2 \pm 0,02$ мг КОН /г. У дослідних зразках цей показник нижчий, ніж у контролі на 5 добу зберігання (мгКОН/г): шинка запечена - 36\%, шинка копчено-варена - 33,3\%, шинка варена - 25\% (рисунок 4).

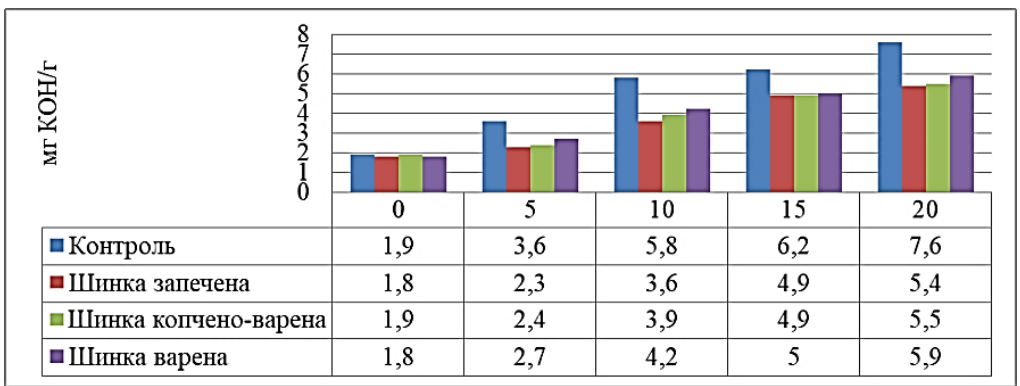

Рисунок 4. Динаміка зміни кислотного числа ліпідів шинок, упакованих під вакуумом, мгКОН /г 
Після 10 діб зберігання процеси окиснення жирів найбільш інтенсивно проходять у контрольному зразку, що свідчить про його псування $(4,3 \pm 0,03$ мг КОН/г), у дослідних зразках через 15 діб

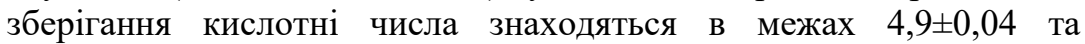
$5 \pm 0,01$ мг КОН /г, тобто зіпсовані.

У шинці запеченій, упакованій під вакуумом під час проведення досліджень, кислотне число було нижчим, ніж у контролі, i становило на 5 добу зберігання у шинці запеченій $-2,3 \pm 0,02$, у шинці вареній $-2,7 \pm 0,01$, на 10 добу $-2,7 \pm 0,01$ та $2,8 \pm 0,02$, на

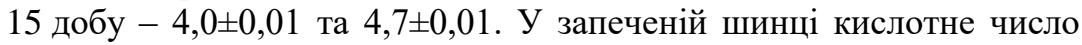
було меншим, ніж у контролі i шинках 3 різною термічною обробкою (рисунок 5).

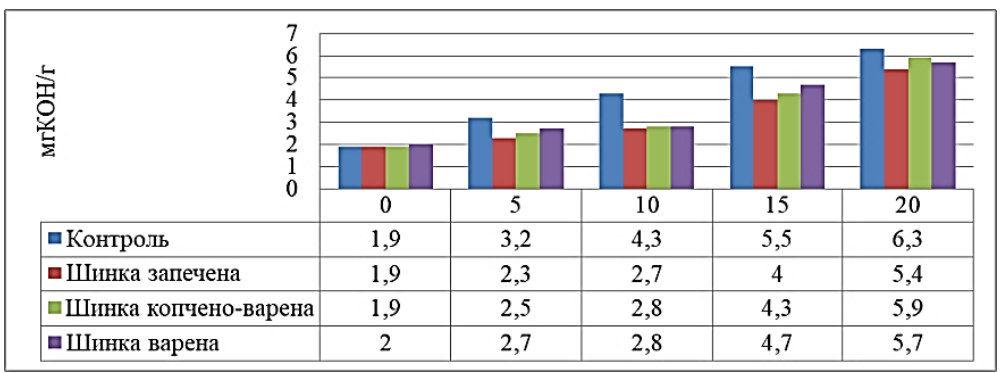

\section{Рисунок 5. Динаміка зміни кислотного числа ліпідів шинки, мгКОН/г}

Перебіг окислювальних процесів у контрольному зразку проходить інтенсивніше. Дослідні зразки шинок зберігають свої якісні показники, їх пероксидне число після 5 діб зберігання на 60\% менше, ніж у контролі, після 10 діб - на 50\% менше, ніж у контролі, і після 15 діб зберігання - в середньому на 30\%. Під час збільшення пероксидного числа жиру у шинках з'являються ознаки прогіркання смаку і неприємного запаху в процесі значенні пероксидного числа жиру $0,2 \% \mathrm{~J}_{2}$.

Зміни пероксидного числа жиру досягають максимальних показників, за якими можна підтвердити псування виробів після 15 діб зберігання за температури $0 \ldots 6^{\circ} \mathrm{C}$ у всіх дослідних зразках, вони знаходяться в межах від $0,11 \pm 0,04$ до $0,12 \pm 0,02 \% \mathrm{~J}_{2}$.

Після 20 діб зберігання в усіх виробах спостерігається утворення перекисів, що призводять до ослизнення та зміни їх запаху. 
У контрольному зразку пероксидне число становило $0,20 \pm 0,02 \% \mathrm{~J}_{2}$, а в дослідних - від $0,15 \pm 0,03$ до $0,18 \pm 0,04 \% \mathrm{~J}_{2}$ (рисунок 6 ).

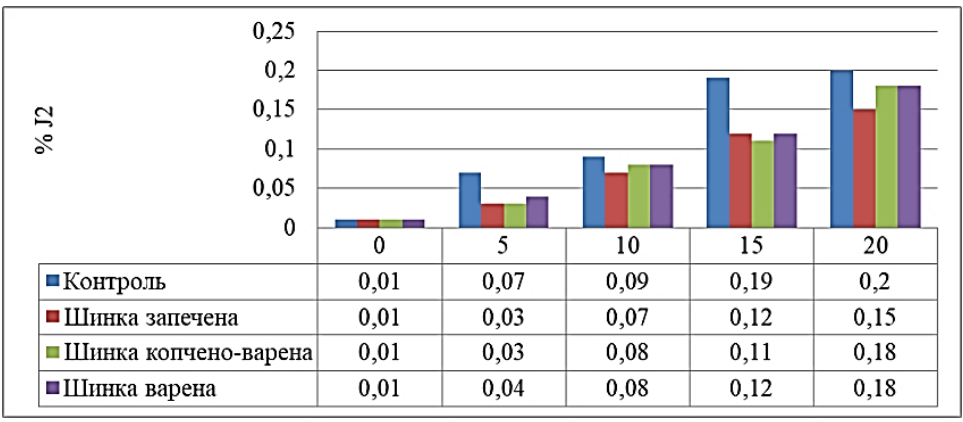

Рисунок 6. Динаміка зміни пероксидного числа ліпідів шинок, упакованих під вакуумом, \% $\mathbf{J}_{2}$

Однак за однакових умов i різного виду зберігання (використання вакуумного пакування) інтенсивність росту пероксидного числа не однакова. Так, через 5 діб зберігання в холодильних умовах значення пероксидного числа становило $0,05 \pm 0,01 \% \mathrm{~J}_{2}$ в контрольному зразку, а через 10 діб - 0,08 $\pm 0,02 \% \mathrm{~J}_{2}$, після 15 діб - 0,12 $\pm 0,02 \% \mathrm{~J}_{2}$.

Пероксидне число жиру в дослідних зразках шинок значно менше, зокрема в запеченій після 5 діб зберігання воно становить

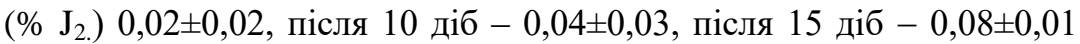
(рисунок 7).

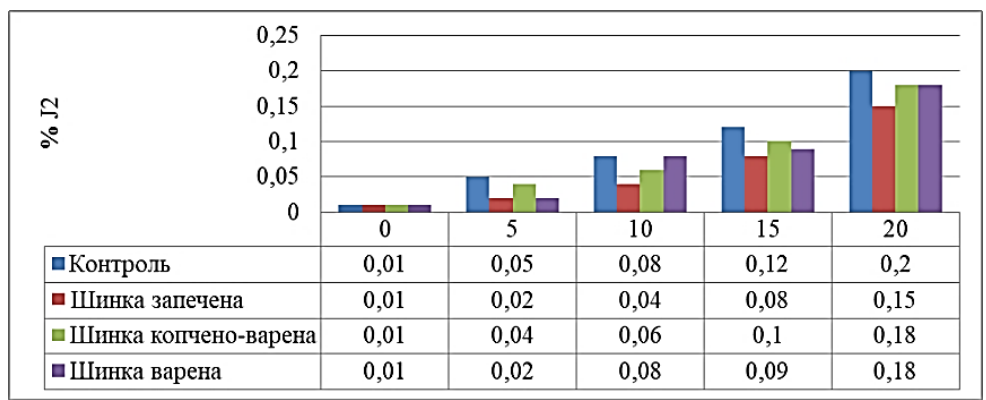

Рисунок 7. Динаміка зміни пероксидного числа шинок, упакованих під вакуумом, \% $\mathbf{J}_{2}$ 
На результати досліджень впливає вміст вологи у виробах, сировина, термічна обробка. Олеорезини, що входять до складу рецептури шинки, здатні призупиняти окиснювальні процеси готових виробів та подовжувати термін зберігання. Контрольний зразок рулету «Курячого» втратив свої якісні показники після 5 діб зберігання, а упакований під вакуумом - після 10 діб. Натомість усі дослідні зразки шинок характеризувались стабільними показниками якості. Процеси псування в них розпочались після 10 діб зберігання, упакованих під вакуумом - після 15 діб.

Дослідження шинок за показниками безпеки, зокрема мікробіологічними показниками, проводили після 15 діб зберігання за температури $0 \ldots 6{ }^{\circ} \mathrm{C}$. Досліджували на вміст кількості мезофільно-аеробних і факультативно-анаеробних мікроорганізмів (таблиця 6). Бактерій групи кишкової палички (колі форми), Staphylococcus aureus в 1 г продукту, патогенних мікроорганізмів роду Salmonella, L. monocytogenes в 25 Г продукту, сульфітредукувальних клостридій, бактерій роду Proteus в 0,1 г продукту не було виявлено.

Таблиця 6

Мікробіологічні показники шинок

\begin{tabular}{|c|c|c|c|c|}
\hline 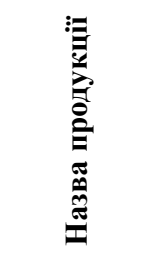 & 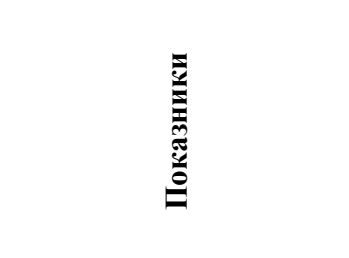 & 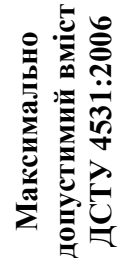 & 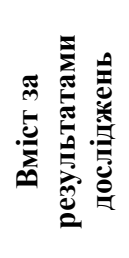 & 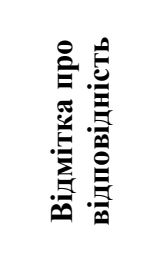 \\
\hline Контороль & $\begin{array}{c}\text { кМАФАМ, КУО в } 1 \text { г } \\
\text { продукту, не більша, ніж }\end{array}$ & $1 \times 10^{3}$ & $1,9 \times 10^{3}$ & $\begin{array}{c}\text { не } \\
\text { відповідає }\end{array}$ \\
\hline $\begin{array}{c}\text { Шинка } \\
\text { запечена }\end{array}$ & $\begin{array}{c}\text { кМАФАМ, КУО в } 1 \text { г } \\
\text { продукту, не більша, ніж }\end{array}$ & $1 \times 10^{3}$ & $2,7 \times 10^{2}$ & відповідає \\
\hline $\begin{array}{c}\text { Шинка } \\
\text { копчено- } \\
\text { варена }\end{array}$ & $\begin{array}{c}\text { кМАФАМ, КУО в } 1 \text { г } \\
\text { продукту, не більша, ніж }\end{array}$ & $1 \times 10^{3}$ & $3,5 \times 10^{2}$ & відповідає \\
\hline $\begin{array}{l}\text { Шинка } \\
\text { варена }\end{array}$ & $\begin{array}{c}\text { кМАФАМ, КУО в } 1 \text { г } \\
\text { продукту, не більша, ніж }\end{array}$ & $1 \times 10^{3}$ & $3,9 \times 10^{2}$ & відповідає \\
\hline
\end{tabular}

Кількості мезофільно-аеробних і факультативно-анаеробних мікроорганізмів (кМАФАМ) у контрольному зразку перевищив допустиме значення $1 \times 10^{3}$ КУО в 1 г продукту і становив $1,9 \times 10^{3}$, що не відповідає вимогам за цим показником та несе потенційну 366 
небезпеку. Загальне бактеріальне обсіменіння дослідних зразків шинок знаходилось у межах норми, найменший показник було виявлено в шинці запеченій - 2,7х10², КУО в 1 г продукту.

У результаті проведених досліджень встановлено, що вакуумна упаковка здатна подовжити термін зберігання продукту втричі, оскільки матеріали, з яких виготовляють поліетиленову упаковку, мають кращі бар'єрні властивості. Олеорезини, що входять до складу рецептури дослідних зразків шинок, володіють антиоксидантними властивостями та призупиняють розвиток мікроорганізмів у готових виробах.

\section{ВИСНОВКИ}

1. За амінокислотним і жирно-кислотним складом оптимізовано рецептуру делікатесного виробу - шинки (вміст м'яса індика - 65\% та кроля - 35\%) та утилітарністю ії організмом.

2. Аналіз результатів усебічного оцінювання розроблених шинок за різних умов теплової обробки свідчить про достатньо високі їхні характеристики: фізико-хімічні, органолептичні, структуромеханічні, та високу біологічну цінність.

3. Встановлено вплив термічної обробки (варіння, коптіння та запікання) на збереження амінокислотного складу готового продукту в такій послідовності: шинка запечена, варена та копченоварена.

4. Доведено підвищення відносної біологічної цінності розроблених шинок (на 28\% порівняно з контролем). Ріст клітин інфузорії Tetrahymena pyriformis є свідченням позитивного впливу на засвоюваність продукту.

5. Встановлено, що зберігання шинок в оболонці «Білкозин» (варена та варено-копчена) та в курячій шкурі (шинка запечена) впродовж 5 діб за температури $0 \ldots 6{ }^{\circ} \mathrm{C}$ та 15 діб, додатково запакованих у вакуумній упаковці, не призводить до суттєвих змін органолептичних, фізико-хімічних і мікробіологічних показників.

6. Результати досліджень мікробіологічних показників повністю підтверджують отримані дані щодо кислотного числа та пероксидного числа під час зберігання розроблених шинок.

\section{АНОТАЦІЯ}

Теоретично обгрунтовано та експериментально підтверджено доцільність використання в технології делікатесних м'ясних виробів (шинок) дієтичного м'яса індика та кроля 3 метою покращення біологічної цінності, технологічних та органолептичних показників якості, гальмування деструктивних перетворень у процесі 
зберігання готового продукту з використанням різних пакувальних матеріалів. У зв'язку з недостатньою науковою інформацією щодо комбінування м'яса індиків та кролів у технології делікатесних продуктів спеціального призначення детальне вивчення хімічного складу, фізико-хімічних, функціонально-технологічних властивостей, структуро-механічних характеристик розроблених шинок за різних методів термічного обробляння (варіння, коптіння та запікання) та показників динаміки змін у процесі зберігання має соціально-економічне значення для подальшого впровадження даної технології на підприємствах м’ясної галузі України.

\section{ЛІТЕРАТУРА}

1. Peshuk L.V., Galenko O.O., Budnik N.V. Use of collagenase in technology gerodietetic products. Journal of food and packing science, technique and technologies. 2014. 2 (3). P. 8-11.

2. Пешук Л.В., Гащук О.I, Москалюк О.С. Інноваційні м'ясні продукти. Харчова промисловість. 2015. 17. С. 64-67.

3. Simonova I., Peshuk L. Galenko J. Microscopic examinayion of chops with content of lentil flour. Ukranian Journal of Food Science. 2019. Volume 7. Issue 1. P.16-26. DOI: 10.24263/2310-1008-2019-7-1-4.

4. Brenes A., Viveros A., Chamorro S., Arija I. Use of polyphenolrich grape by-products in monogastric nutrition. A review. Animal Feed Science and Technology. 2016. Volume 211. P. 1-17. DOI.org/10.1016/j.anifeedsci.2015.09.016.

5. Dal A., Simona B., Marco C. M., Szendrő Z., Gerencsér Z., Matics Z., Castellini C., Szin M., Zotte A. Effect of diet and packaging system on the oxidative status and polyunsaturated fatty acid content of rabbit meat during retail display. Meat Science. 2018. Volume 143. P. 46-51. DOI.org/10.1016/j.meatsci.2018.04.004.

6. Спосіб виробництва сиров'ялених продуктів із м'яса індиків і кролів «Торіно»: пат. на винахід 104679 Україна: МПК 51 А 23 С. 11 /00 / Пешук Л.В., Дидюк О.Ю., Дубяга О.М; власник НУХТ. № a201214239; заявл. 13.12.2012; опубл. 25.02.2014, Бюл. № 10.

7. José Manuel. Identification and quantification of turkey meat adulteration in fresh, frozen-thawed and cooked minced beef by FT-NIR spectroscopy and chemometrics. Meat Science. 2016. Volume 121. P. 175-181. DOI.org/10.1016/j.meatsci.2016.06.018

8. Cullere M., Dalle A., Zotte, Tasoniero G., Giaccone V., Szendrő Z., Szín M., Odermatt M., Gerencsér Z., Dal Bosco A., Matics Z. Effect of diet and packaging system on the microbial status, $\mathrm{pH}$, color and sensory traits of rabbit meat evaluated during chilled storage. 
Meat Science. 2018. Volume 141. P. 36-43. DOI.org/10.1016/ j.meatsci.2018.03.014.

9. Mancini S., Nuvoloni R., Pedonese F., Paci G. Effects of garlic powder and salt additions in rabbit meat burgers: Preliminary evaluation. Food processing and precervation. 2019. Volume 133,3. P. 1-10. DOI.org/10.1111/jfpp.13894.

10. Ding Y., Lin H.-W., Lin Y.i-L., Yang D.-J., Yu Y.-S., Chen Jr.W., Wang S.-Y., Chen Y.-C. Nutritional composition in the chia seed and its processing properties on restructured ham-like products. Journal of Food and Drug Analysis. 2018. Volume 26 (1). P. 124-134. DOI.org/10.1016/j.jfda.2016.12.012.

11. Youling J. J., Xiong L. Natural antioxidants as food and feed additives to promote health benefits and quality of meat products: $A$ review. Meat Science. 2016. Volume 120. P. 107-117. DOI.org/10.1016/j.meatsci.2016.04.005.

12. Mattioli S., Dal Bosco A., Szendrő Zs., Cullere M., Gerencsér Zs., Matics Zs., Castellini C., Dalle Zotte A. The effect of dietary Digestarom herbal supplementation on rabbit meat fatty acid profile, lipid oxidation and antioxidant content. Meat Science. 2016. Volume 121. P. 238-242. DOI.org/10.1016/j.meatsci.2016.06.024.

13. Dalle A., Zotte C., Celia Zs., Szendrő. Herbs and spices inclusion as feedstuff or additive in growing rabbit diets and as additive in rabbit meat: A review. Livestock Science. 2016. Volume 189. P. 82-90. DOI.org/10.1016/j.livsci.2016.04.024.

14.Маркович I.I. Зміни мікробіологічних показників напівкопчених ковбас у процесі зберігання. Наукові доповідi Національного університету біоресурсів $і$ природокористування України. 2015. № 3. URL : http://nbuv.gov.ua/UJRN/Nd_2015_3_18.

15.Drachuk U., Simonova I., Halukh B., Basarab I., Romashko I. The study of lentil flour as a raw material for production of semi-smoked sausages. Eastern-european journal of enterprise technologies. 2018. № 6. 11(96). P. 44-50. DOI:10.15587/1729-4061.2018.148319.

Information about the authors: Peshuk L. V., Doctor of Agricultural Sciences, Associate Professor

Simonova I. I.,

Candidate of Technical Sciences, Department of Technology of Meat, Oil and Fat Products Stepan Gzhytskyi National University of Veterinary Medicine and

Biotechnologies 50, Pekarska str., Lviv, 79010, Ukraine 